\title{
PREMISE OF OPTIMAL WATER MANAGEMENT IN LATVIA
}

\author{
Gunārs Zaḳis and Raimonds Ernšteins \\ Institute for Environmental Science and Management, University of Latvia, Raina bulv. 19, Rīga, LV-1586, LATVIA \\ E-mail: gunars.zakis@lu.Iv; raimonds.ernsteins@lu.Iv
}

Communicated by Jānis Kristapsons

\begin{abstract}
The development of water management in Latvia was broadly investigated with a focus on identifying the main managerial problems when analysing all factors affecting water administration and management optimisation prospects. Combined sociological research was performed using traditional and also case study research methodologies to produce systemic assessment of institutional and human resource capacities and managerial impact on the organisational ability of municipalities and the provision of water supply and waste water treatment services by companies and utilities. Alternative water management models and their applications were also elaborated and evaluated. To provide rational use of water resources in Latvia and to meet the requirements of the $E U$ legislation, it is necessary to change the water management system in the country, but, most important, to develop principles of systemic integration and coordinated cooperation with respecting historically formed conditions, and, to introduce an optimal water management model comprising a set of management preconditions-approaches, principles, structural components and set of tools into complement institutional capacities.
\end{abstract}

Key words: water administration and management improvement, local municipalities, regional reform, integration and cooperation, coordinated decentralization.

\section{INTRODUCTION}

Water management is important worldwide (Shiklomanov and Rodda, 2004) and in Latvia particularly after joining the European Union (EU) in 2004 due to the ongoing administrative and territorial reform. The theoretical background of water management is included in the European Water Framework Directive 2000/60/EC (WFD). The document envisages unified protection of all surface and ground waters in order to provide good water resource quality for all EU Member States. Its implementation is based on introduction of integrated water resources management (IWRM) principles (Anonymous, 2002) and the development of management systems for river catchments areas (Rahaman and Varis, 2005; Bresser and Kuks, 2004). Due to historic reasons, the initial situation in Latvia greatly differed from that in other EU Member States, the two neighbour Baltic countries including, but in all countries the IWRM process is still ongoing and local characteristics need to be taken into account (Gooch and Stalnacke, 2006).

In compliance with European WFD, the National Water Management Law was adopted (2002), which envisages good water quality of all surface waters and ground waters by 2015 . The improvement of management in water utilities and carrying out measures for strengthening of institutional capacity are prescribed by the National Environmental Policy Plan for the years 2004-2008 and the Water Management Infrastructure Development Programme (2006). The
Law on Local Governments (1994) states that organisation of water supply and waste water treatment for residents is the responsibility of local municipalities. The total number of municipalities in the country has continuously changed during the last decade, but still exceeds more than 500, indicating differing ability to provide water management services in relation to the capacity of institutional and human as well as financial resources. It is planned by 2007-2009 to decrease this number by five times, according to the Law on Administrative-Territorial Reform (1998) by integration of small local municipalities into bigger ones. However, the status of regional or second level municipalities is still unclear. In this situation an answer had to be found to the question: what will happen to the existing water management utilities after integration?

This study considers the set of problems related to the historic development of water management (water supply and waste water treatment) in Latvia, the introduction of integrated water resources management principles in the country, and also, the main directions of water management optimisation in the context of regional reform. These are selected topics from the whole spectrum of water management issues and, subsequently, this study focuses on management and administration rather than on technology and financial resource optimisation, but particularly on the process directed towards the continuing management improvements and covers the identification, assessment, planning, introduction and control of policy decisions and alternative 
solutions of the existing water management problems. An interdisciplinary approach of water management is needed that includes the traditional engineering and nature sciences combined with economics and social sciences, aimed at new management and for sustainable water resource development (Stephelson, 2003).

This kind of historically-originated, unique overlapping of several circumstances on the same time scale, and their considerable influence on the development processes in the country as well as the sustainable development paradigm for new century, require carrying out of water management optimisation in Latvia.

Compared with other countries, the water management situation in Latvia is unique, it is determined by historical circumstances developing over the last 20 years. Water management was highly centralised and controlled by the Soviet governance. There were some advantages of this kind of management as the central government had direct control over the entire water management system at all levels, but there was disunity of water management among different branches of economy, lack of a unified concept of administration and development, finally resulting into inefficient operation, low quality of services and environmental problems. In the $1980 \mathrm{~s}$, new rural villages, animal husbandry farms and mechanic workshops with centralised water supply and waste water treatment were built in Latvia. They were managed by collective farms governed by the Ministry of Agriculture. Regional centres, towns and rural villages not belonging to this category were served by public utilities-small-scale many-branched utilities or companies, where water management was just one field of work among many others. These companies were located in central cities of regions with branches in towns or villages. In terms of administration they were subordinate to the Ministry of Public utilities, but in terms of functions, to local governments. Big state-owned companies, subordinate to ministries of corresponding branches, managed their objects themselves, but Riga had its own independent water supply and sewerage utility.

In 1991, after regaining the independence, change in the ownership of all water facilities took place. They were privatised by different organizations and private persons, taken over by municipalities, but some were left as abandoned property. $70 \%$ of more as 500 municipalities of that time were small or very small in terms of population and territory, lacking financial and human resource capacity (Vanags and Vilka, 2005). Only some municipalities could afford to renovate and properly maintain their water facilities, mainly by attracting EU and governmental investments and using their own co-financing. Most facilities were old and worn out, but many municipalities still lack water facilities and water utilities of their own and even lack competent personnel for the management of such facilities. They fully depend on the owners of the water facilities, who offer them water supply and waste water treatment both in terms of service quality and tariffs. Private persons and companies had to cover $100 \%$ of all expenses related to renovation of water facilities from their own income. Therefore, they either did not carry out these changes at all or they established high tariffs. The main problem was defined as an inability or unwillingness of owners of water utilities to adequately maintain their facilities.

Although the existing water management model has not been widely studied in Latvia, it is clear that it can be characterised by a big number of water supply and waste water treatment services offered by companies, which are much different in size and stage of development. It is a contingency decentralisation with some established water management utilities and owners. Often they are not able to meet the water supply and waste water treatment requirements of municipalities, to offer high quality services to all residents and reduce risk to human health, they suffer financial losses and environmental pollution is common. The main disadvantage of water management in Latvia is insufficient scientific research, resulting in a lack of theory-based recommendations and the lack of shared or agreed scenarios and instruments for further development of water management. For example, the national water management programme „800+”, „Instrument for Structural Policies for Pre-accession" (ISPA), now replaced by the "Cohesion Fund", Special Action Programme for Agriculture and Rural Development (SAPARD) etc can be mentioned as important water management development projects in Latvia. Nevertheless, the former water management can be characterised as spontaneous, uncoordinated and inefficient, and its optimization is a topical issue on national, regional and local levels.

This study, subsequently, aims at systemic analyses of related factors and preconditions and further on the development of an optimal water management model for Latvia to be successfully applied.

\section{MATERIALS AND METHODS}

The study was carried out during the period of 2001-2007 as a several complementary sets of research instruments. Combinations of different research methods were used to analyse water management system situations and assess change and internal developments, particularly by applying the following methods: (i) initial expert and official (more as 100 persons) survey, (ii) specialist and decision maker (15-20 persons for every of three periods) interviews, (iii) specific case studies (more then 50 cases) using surveys, interviews, documentation and observation studies) for all vertical administrative levels in the country and crosssectorial horizontal issues for all diverse organisational and management cases possible, e.g

\section{- household level,}

- municipal and private water management enterprises, for example, Salacgrīva KdzSU, SIA „Ainažu KUK”, SIA "Saltavots”, SIA „Ziemeḷkurzeme”, SIA "Vinda” in Cēsis, SIA "Rīgas Ūdens”, SIA „Jelgavas Ūdens”, SIA 
"Liepājas Ūdens", SIA "L4", SIA "CalrBro", SIA „Ekostandarts Tehnoloğijas”, etc.;

- local municipalities, for example, Salacgrīva, Ainaži, Staicele, Aloja and Limbaži (Limbaži District), Cēsis (Cēsis Distr.), Saulkrasti, Sigulda and Rīga (Rīga Distr.), Jelgava (Jelgava Distr.), Aizkalne (Preili Distr.), Ezere, Nīgrande and Nīkrāce (Saldus Distr.), Jaunpagasts, Laidze, Strazde, Roja, Kolka, Mazirbe, Pūrciems, Gipka, Vīdāle and Dundaga (Talsi Distr.), Liepāja (Liepāja Distr., Pope (Ventspils Distr.), etc.;

- regional level, e.g. Regional Environmental Protection boards of the Ministry of the Environment (Lielrīga region, Valmiera region, Jelgava region etc), as well as River Salaca Basin Management Consultative Board, River Daugava Basin Management Project, etc;

- national level e.g. Ministry of the Environment and subordinated bodies, Self-Government Union of Latvia as well as research institutions and organisations, etc.

A systemic approach was applied in the study for the assessment of geographical location, historical development, financial and human resources capacity impact on the ability of municipalities to organise and the ability of companies and utilities to provide water supply and waste water treatment. Assessment of water management administration over the period of last 20 years and at the present was conducted using induction and deduction methods, logframe and SWOT (S - Strength, W - Weakness, O - Opportunities, $\mathrm{T}$ - Threats) analysis, as well as professional experience. In the process of development of an optimal water management model, alternatives were developed and the following internal factors like pollution reduction, management efficiency of river catchments areas, quality of services, condition of technical systems, water consumption, losses, competence and capacity of personnel, institutional capacity, etc. were assessed for each of them.

\section{RESULTS}

The results described were based on cyclic research phases of this study during 2001-2007 having related repeating phases (especially before and after Latvia had joined WFD at 2004) of applying all research tools mentioned above, being combined together by structured interviews and questioning of all level experts and specialists involved in water management. To ensure objective results, survey included respondents from different stakeholder groups in all regions and diverse types of local municipalities. The study showed, e.g., that before Latvia harmonised the WFD in legislation, only $1 \%$ of all respondents were satisfied with the current situation, but $67 \%$ considered that the existing water management model should be changed. Moreover, most respondents considered that provided such changes would be carried out, several municipalities should cooperate and establish one common water utility (Zakis, 2003).
An assessment of the efficiency of services offered by the water management sector in Latvia during recent years (2004-2007) was made in this study to answer the question: how the existing water management structure has been elaborated (but not yet changed) by more rational use of the existing resources. Low efficiency of water utilities is suggested by the small number of residents to whom services are supplied, absence of an amalgamation process among the small enterprises in the water management sector in Latvia, water utilities allowing considerable (and sometimes even unregistered) water losses in their systems and incomplete securing of payments for the consumed water.

Preconditions for improvement of water management efficiency in Latvia are as follows: first and obviously, investment in modernisation of equipment and technological processes and, second, institutional and human resource capacity building of enterprises. To carry out optimisation, changes in the existing structure are necessary-identification and implementation into practice of new structural elements and cooperation channels and elimination of old ones, resulting into coordinated operation and complementarity of all qualitative levels of water utility. New management models are required. SWOT analysis showed a weak management system, worn-out equipment and big feasibility differences among municipalities, and the main "strength" was legislation in compliance with EU directives and introduction of IWRM at the national level (Zakis, 2007).

The introduction of IWRM in Latvia is characterised by the following external factors: (i) the historical situation in the field of ownership of water facilities after the change of regime in 1991, (ii) factors creating obstacles for the development of a business environment (adoption of new legislation with frequently adopted amendments, undeveloped business environment, change of currency in the country, inflation etc.), (iii) inability or unwillingness of water facility owners to supply consumers with drinking water of the required quality and discharge of insufficiently treated waste water into environment, (iv) contradiction between the responsibility of municipalities to organise water supply and waste water treatment in their territories, defined by legislation and (v) lack of financial or human-intellectual resources or lack of water facilities in general to provide these services, (vi) postponed regional reform (failure in meeting deadlines, lack of decisions on the governmental level, unclear future etc.), (vii) insufficient cooperation experience among municipalities, between municipalities and the government, municipalities and owners, etc., and (viii) water use related customs (e.g. washing in running water, using drinking water for watering gardens), etc.

Also, the following main problems (inner conditions) of IWRM introduction are recognised: (i) low capacity of municipalities (insufficient intellectual potential, lack of financial resources, lack of qualified employees and other resources), (ii) uncoordinated water management administration and information dissemination at both horizontal and vertical levels (among local municipalities, among local 


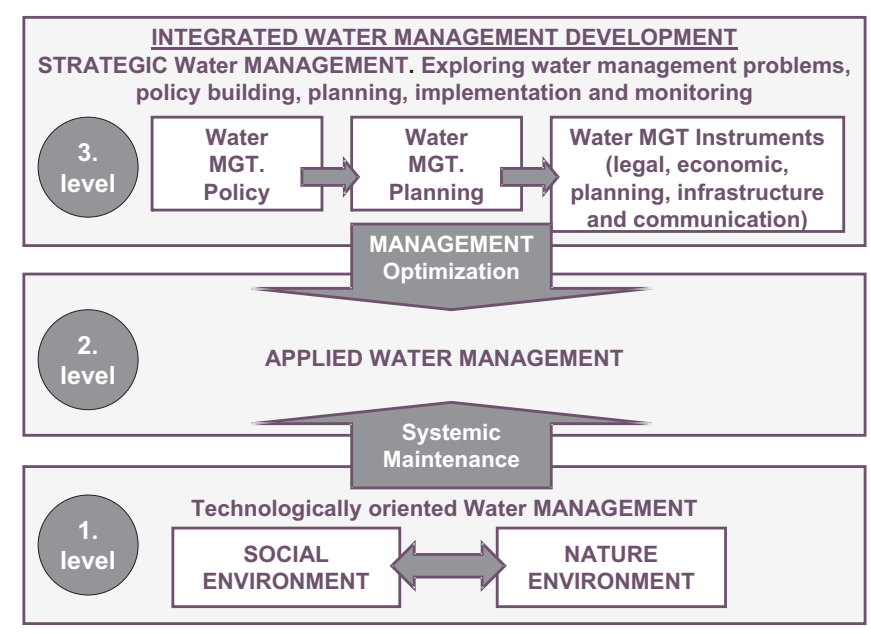

Fig. 1. Qqualitative levels of water management functioning.

municipalities and government, among local municipalities and owners of water facilities etc.), (iii) inability or strong unwillingness of water facility owners to participate in introduction of IWRM, (iv) vague regional reform, (v) low paying capacity of the population, (vi) insufficient motivation, (vii) indifferent attitude by local communities, (viii) low population density and too few consumers, (ix) improperly arranged financing, (x) institutionally weak structure, (xi) underdeveloped regions, far from populated areas etc.

In order to be able to assess the quality of water management services, three qualitative levels of providing functioning of water utility were elaborated during the study and defined (Fig. 1). The lowest one is technologically oriented water management-extraction, treatment and supply of drinking water, waste water collection and treatment, information dissemination and other unstructured implementation, where each function is performed separately, hardly overlapping with other functions and without any cooperation between institutions. The next level is applied water management-management arranged in terms of functions, sectors and hierarchy, where sectoral horizontal cooperation among functions and performing institutions as well as hierarchic vertical cooperation among different levels of supervising institutions is introduced. The highest level is integrated water management-a process coordinated by strategic documents of development of water management (policy concepts, guidelines, strategic action programmes etc.) and realised by policy instruments (e.g. economic, communicative, financial, administrative control etc.). Clearly defined water management policy means defined policy aims, principles, preconditions, approaches and instruments to achieve them.

In the course of the study, a model of optimal water management with elements of integration and cooperation was elaborated (Fig. 2). This model comprises all three administration levels-national, regional and, particularly, local level, with special focus also on vertical and horizontal cooperation links (Zaķis, 2007).

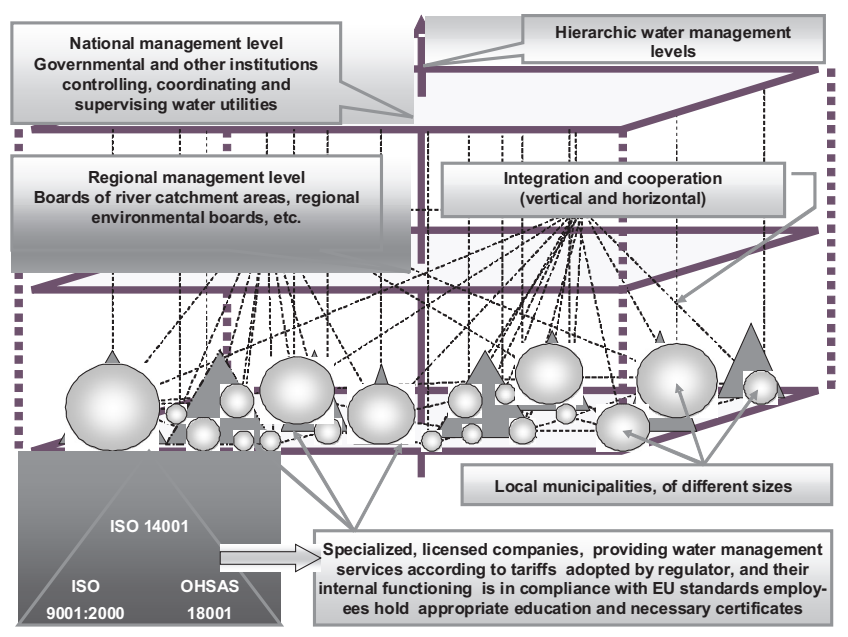

Fig. 2. Model of optimal water management with integration and cooperation elements.

National level constitutes water management control, coordination and supervision by governmental institutions, which do not perform direct administration, but develop and implement water management regulating legislation and control its enforcement. For example, legislation and policy documents are developed and their implementation is controlled by the recently (April 2005) established Unit of Water Resources at the Ministry of Environment (Anonims, 2004). The regional level is covered by the boards of river catchments areas and regional environmental boards, and the local level by municipalities and companies offering water related services (Anonīms, 2007).

During the study a concept was developed for the local level-municipalities and water utilities. Organisation of water supply and waste water treatment for residents is a responsibility of local authorities (Anonīms, 1994). Municipalities can enforce the provisions of the law by establishing their own water utility or contracting this function to other, already existing utilities. Results of the study confirm that the most optimal case is when a large municipality or region establishes its own water utility, or smaller municipalities cooperate and establish one joint water utility. In order to offer municipalities specific actions and stream of their implementation for the optimisation of water management, an optimisation algorithm was elaborated, starting with identifying water facilities in the respective administrative territory to IWRM implementation.

At present, broad renovation of the existing water utilities or building of new ones has started. However, the focus should be placed on the institutional alignment. This means that updating of technologies, development of utilities and administration capacity building are of equal importance (Zakis, 2003).

Water utilities should be specialised and licensed for providing water management services according to tariffs adopted by a regulator. Employees should have the prerequisite education and qualification and necessary certificates, corresponding to the positions they have in the utility, and 


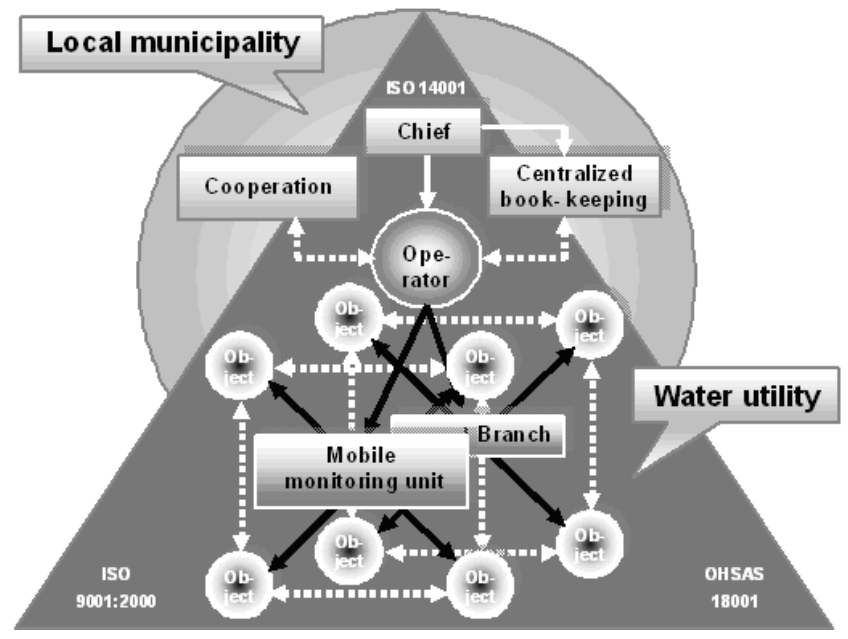

Fig. 3 Model of optimal water utility administration.

internal regulations should be defined in compliance with EU standards, for example, by introduction of an environmental management system according to ISO 14001:2004 standard requirements, quality management system according to ISO 9001:2000, work safety and health management system OHSAS 18001 (Occupational health and safety information standard), etc. Standards should be introduced not only in the water utility, but also in the municipality. The EMAS (Eco-Management and Audit Scheme) is considered to be the most appropriate environmental management system for municipalities. It should be noted that at present this kind of requirement is not obligatory and depends only on the goodwill of utility owners or municipality leaders. Moreover, some activity areas are not yet licensed in Latvia. Figure 3 shows a more detailed model of optimal water utility administration. As one can see in the scheme, a water utility has central administration headquarters and branches. Work is coordinated by a dispatching control service. Mobile units are used for maintenance of water facilities or emergency services. A separate external cooperation unit works with customers, municipalities, controlling institutions, other bodies.

Figure 2 shows that integration and cooperation with other sectors and levels is essential. Therefore, a model (Fig. 4) of information coordination and communication system (Ernsteins, 2005) was elaborated, putting accent on cooperation links and their directions among municipalities, water utilities and different institutions - management boards of river catchments areas, higher educational institutions etc. This kind of model should provide all stakeholders an access to up-to-date and broad information on water utility (Anonīms, 2003). For example, every resident should have an opportunity to find out what kind of research is carried out by what higher educational institution and what are the main results (different projects, MSc and Doctoral thesis) (Borowski and Hare, 2007), what is the drinking water quality in any place of the country, what are the water and waste water treatment tariffs in any municipality in the country etc., and local municipalities should be provided with information related to decision making and enforcement.

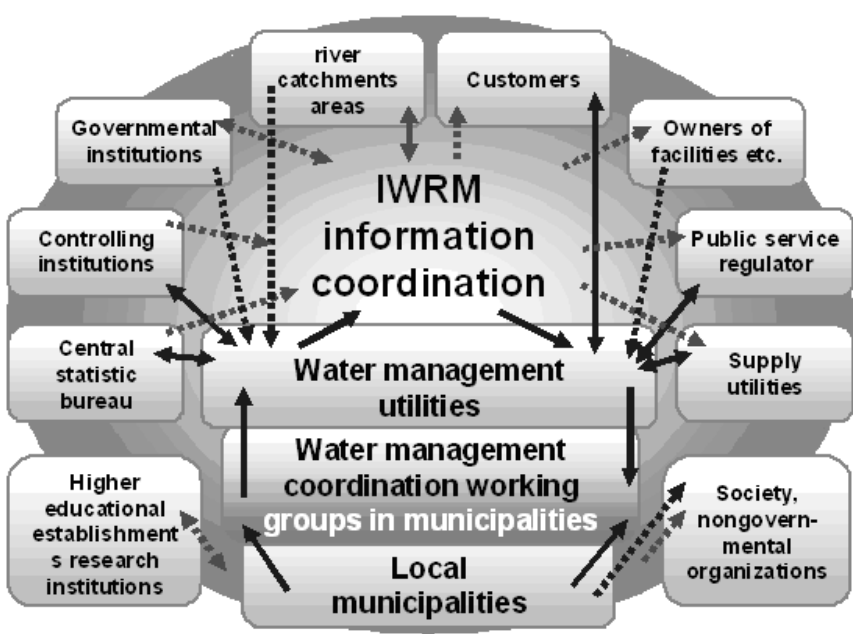

Fig. 4 Model of information coordination and communication system.

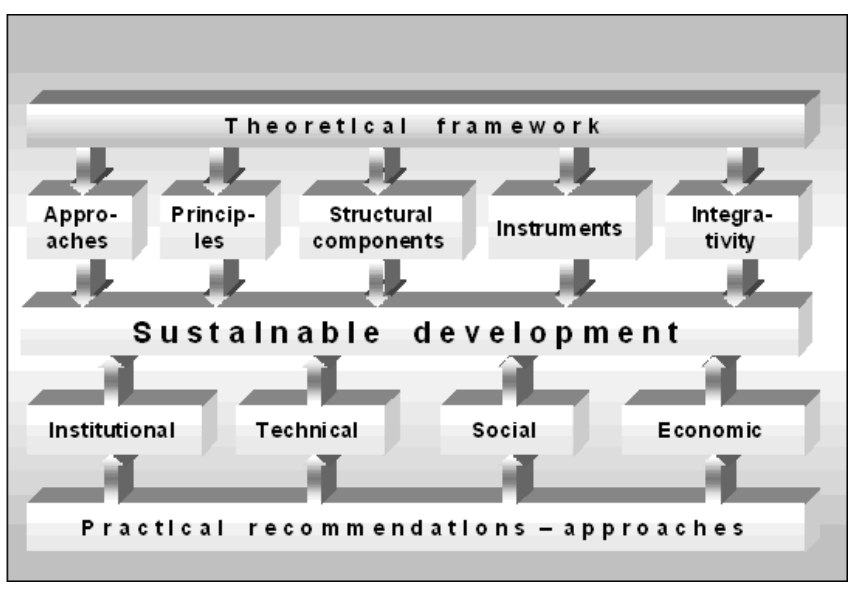

Fig. 5 Model of optimal water management-complementary package.

According to the results of the study and the developed support models, an optimal water management model was developed for Latvia (Fig. 5). Intermediary results applied together are giving an opportunity to design the main directions for an optimal water management with the defined set of interrelated preconditions-approaches, principles, structural components, instruments and integration conditions as well as practical recommendations. Here they are extended with subcomponents to be taken into account:

1. Approaches. Water management in Latvia is optimal, if the following approaches are applied (Zakis, 2007; Ernsteins, 2006):

1.1. water management model has adapted a full environmental management four-stage cycle (problem definition, policy, planning, programmes) and in each stage of the cycle,

1.2. specific character of historically formed conditions is respected.

2. Principles. Water management in Latvia is optimal, if: 
2.1. systemically integrated, purposeful water management policy with defined basic principles is integrated in social, economic and institutional sector at horizontal and vertical levels;

2.2. it is characterised by the coordinated cooperation principle:

2.2.1. vertical-hierarchic-administration levels: country, regions, and local municipalities, with the tendency to decentralisation,

2.2.2. horizontal administration levels: among governmental institutions, regions, municipalities, water utilities etc.

3. Structural components. Main structural components of water management optimisation in Latvia are:

3.1. institutional capacity building of water utilities,

3.2. optimisation of municipality administration by introduction of Environmental Management and Quality Management Systems,

3.3. horizontal (management of river catchments areas) and vertical (integrated water resources management) optimisation-complex management is provided at all water management levels,

3.4. optimisation of cooperation-coordinated mutual systemic links of interaction.

4. Instruments. Water management in Latvia is optimal, if the complementary package of main water resources management instruments is put into practice:

4.1. legislation (Water Management Law, regional reform, binding regulations for local municipalities, development strategies, territorial planning etc.),

4.2. economic instruments (taxes encouraging environmental protection and saving water resources, subsidies etc.),

4.3. comprehensive communication (information, education, public participation and environmental behaviour enhancement towards individual and traget groups awareness development),

4.4. sufficient capacity of services providing human and financial resources,

4.5. modern and specific needs meeting infrastructure.

5. Integration conditions. Basic conditions for optimisation of water management administration in Latvia:

5.1. introduction of integrated water resources management (IWRM) into all levels, based on basic principles of management and sustainable development of river catchments areas, supported by a unified administration and information coordination and communication system for process management and information dissemina- tion at vertical (spectrum internal) and horizontal (cross sectorial) levels and among target groups; as well as efficient work organisation, using comprehensive quality management systems, best available technologies and rationally using drinking water,

5.2. effective complementarity of integrated, applied and technologically oriented water management, providing basic functions of water management policy and planning and increased efficiency.

6. Approaches of practical recommendations:

6.1. institutional approach-institutionally arranged water utilities, where the output, quality and development possibilities of water supply and waste water treatment services do not depend on financial and intellectual capacity distinctions of municipalities,

6.2. technical approach-modernisation of technologies and technological processes to meet principles of sustainable development,

6.3. social (restriction) approach:

6.3.1. in order to protect public benefit and efficiently use drinking water resources, the water management sector in municipalities should be restricted, because non-envisaged free market competition in water supply and sewerage-the monopoly type and prime necessity services providing field - is not allowable,

6.3.2. wealthy water consumers should cover costs of low income consumers (however, this kind of subsidising of service provider can lead to biased pricing policy and demand).

6.4. economic approach:

6.4.1. municipalities should establish that bigger water consumers are set higher tariffs, because one common tariff, not related to the amount of consumed water does not encourage sustainable water consumption;

6.4.2. to prevent water spills and encourage use of best available water saving technologies in the production, municipalities should establish a specific water consumption limit for the given tariff; a new, much higher tariff should be set after passing this limit;

6.4.3. to maintain a sound system, municipalities should apply direct subsidies more broadly;

6.4.4. municipalities should subsidy utilities-water suppliers, rather than water consumers.

All the elements of this coherent whole system for integration and cooperation reinforce each other and all together can steer water management system improvement towards sustainable development one. 


\section{DISCUSSION}

The comparison of global water management problems (Gordon et al., 2004) and newly acquired findings of this study on the situation in Latvia confirm that generally recognised and defined water management problems are typical also for this country, e.g., insufficient attention by the government and competency of local governments in solving water management problems, lack of investments into water sector, narrow sector-related and fragmented management of water resources, lack of information and data for the effective water management etc. However, they become most apparent on different management levels. For example, inefficient water management supervision on the national management level, insufficient capacity of municipalities and water utilities in solving water management related problems on local level and lack of information coordination on all levels.

In addition to the mentioned ones, there are problems typical for Latvian conditions, particularly in coastal areas, caused by relationships between owners of water facilities and municipalities. For example, organisation of water supply and waste water treatment in their respective territories is the responsibility of the municipality; however, municipalities might face serious problems in doing that properly, in cases when they lack water facilities of their own, as they are owned by companies or private persons (Zakis, 2004). Owners may have problems in maintaining their water facilities properly and provide services, particularly if their main operation profile is different from water management (for example, fish processing companies). Moreover, municipalities cannot provide any help to the owners since they neither have any own budget share nor EU structural funds allocated for investments into renovation and reconstruction of water facilities belonging to owners other than municipalities. A paradoxical situation has formed where municipalities might be able to maintain water facilities and provide services to local residents, but the municipality does not own them; but at the same time private owners of water facilities are unable or unwilling to maintain them properly, at the same time fixing inadequately high tariffs for their services. In this case several alternative actions have been developed, which have been monitored. Solutions can be achieved only by negotiations, achieving a compromise, satisfying all stakeholders. This process may last up to several years. However, if agreement can not be achieved even in this case, then municipalities should find a possibility to build their own water facilities (Zakis, 2006).

The optimal water utility in Latvia can be characterised by a coordinated decentralisation management model, with integration and cooperation for all cross-sectorial and crosslevel interlinked management issues, where:

- at the national management level the government organises supervision, coordination and control,

- at a regional level where municipalities get involved in management of river catchments areas by cross-border cooperation in the field of monitoring and carrying out environmental protection measures, and

- at the local level-municipalities by means of their own or attracted resources (financial, human, water facilities etc.) directly provide water management services to local residents (Zakis, 2003).

In order to distinguish between water management situations when market regulations work well or can fail, application of additional planning and monitoring procedures are recommended. This would allow assessment of the need for interference by the government in cases of improper use of resources, particularly in cases when competition is not completely free, consumers are not well informed and water supply may result in social tension. Also, after analysis of the current situation, the authors conclude that there is growing interest in the country towards public-private partnership developments (Richardson, 2002).

This study have been realized not only as a statistic water management system assessment, but mostly as an active participation based case study of different local and regional water management processes passing through stages of analyses and design, decision making and test implementation, comparison and recommendation elaboration. The results of this water management development overview study could be directly applied into national and especially local management level as academic and practical recommendations for the water management system in transition from command-and-control approach to a market economy approach.

\section{ACKNOWLEDGEMENTS}

The author wishes to thank the University of Latvia and the European Social Fund for support in carrying out this study.

\section{REFERENCES}

Anonīms (1994). Likums. Par pašvaldībām [Law on Local Governments]. LR Saeima. 09.06.1994. Latvijas Vēstnesis, No. 61(192), 24.05.1994

Anonīms (1998). Likums. Administratīvi teritoriālās reformas likums [Law on Administrative-territorial Reform]. LR Saeima. 13.11.1998. Latvijas Vēstnesis, No. 322/325(1383/1386), 30.10.1998.

Anonīms (2002). Likums. Ūdens apsaimniekošanas likums [Law on Water Management]. LR Saeima. 15.10.2002. Latvijas Vēstnesis, No. 140(2715), 01.10.2002.

Anonīms (2003). Nacionālais vides politikas plāns 2004-2008 [National Environmental Policy Plan 2004-2008]. Rīga: LR Vides ministrija.

Anonīms (2004a). EMAS ieviešanas rokasgrāmata pašvaldībām [Manual on EMAS Introduction for Municipalities]. UBC, EMAS Peer Review for Cities project. http://www.virums.lv

Anonīms (2004b). LR Ministru kabineta Noteikumi Nr. 4. Vides pārraudzības valsts biroja nolikums [Regulations of Cabinet of Ministers, Republic of Latvia, No. 4, Regulation of environmental supervision state bureau]. 06.01.2004. Latvijas Vèstnesis, No. 4, 09.01.2004.

Anonīms (2006). Ūdenssaimniecības infrastruktūras attīstība apdzīvotās vietās ar cilvēku ekvivalentu lìdz, 2000 [Development of Water manage- 
ment Infrastructure in Populated Areas with Human Equivalent up to 2000]. Nacionālā programma. Rīga: LR Vides ministrija.

Anonīms (2007). Ūdens resursi: plānošana un apsaimniekošana pašvaldībās [Water Resources: Local Planning and Management). Rīga: Vides projekti. $324 \mathrm{lpp}$.

Anonymous (2000). Directive 2000/60/EC of the European Parliament and of the Council establishing a framework for the Community action in the field of water policy. http://ec.europa.eu/environment/water/water-framework/index_en.html

Anonymous (2002). Integrated Water Resources Management. Background Paper No. 4. GWP Technical Committee http://www.gwpforum.org

Anonymous (2006). Topics on System Analysis and Integrated Water Resources Management. Castelletti, A., Sessa, R.S. (eds.). Elsevier. 304 pp.

Anonymous (2008). ToolBox for Integrated Water Resources Management. http://www.gwptoolbox.org/

Borowski, I., Hare, M. (2007). Exploring the gap between water managers and researchers: Difficulties of model-based tools to support practical water management. Water Res. Management, 21(7), 1049-1074.

Bressers, H., Kuks, S. (eds.) (2004). Integrated Governance and Water Basin Management: Conditions for Regime Change and Sustainability. Dordrecht-Boston-London: Springer (Kluwer Academic Publishers). $269 \mathrm{pp}$

Ernsteins, R. (2005). Coastal Communication and Partnerships for Municipal Sustainable Development. In Management and Conservation of Coastal Natural and Cultural Heritage. Proceedings of International Conference, Aveiro University, Portugal (pp. 21-27). Aveiro.

Ernsteins, R. (2006). Local Agenda 21 Process Facilitation: Environmental Communication and Self-Experience Development in Latvia. In Sustainable Development in the Baltic and Beyond (pp. 305-318). Filho, L.W., Ubelis, A., Berzina, D. (eds.). Frankfurt: Peter Lang Europaischer Verlag der Wissenschaften.

Gooch, G., Stalnacke, P. (2006). Integrated Transboundary Water Management in Theory and Practice: Experiences from the New EU Eastern Borders. London: International Water Association Publishing. 256 pp.
Rahaman, M., Varis, O. (2005) Integrated water resources management: Evolution, prospects and future challenges. Sustainability: Science, Practice, \& Policy, 1(1), pp. 15-21.

Richardson, A. (2002). Development of an Expert System for Evaluation of Public Private Partnerships for the Water Industry. Civil Engineering in SA.

Stephenson, D. (2003). Water Resources Management. Netherlands. 322 pp.

Shiklomanov, I.A., Rodda, J.C. (eds.) (2004). World Water Resources at the Beginning of the Twenty-First Century. Cambridge, UK: Cambridge University Press. $449 \mathrm{pp}$.

Vanags, E., Vilka, I. (2005). Pašvaldību darbība un attīstība [Activity of Self-Government and Development]. Rīga: Latvijas Pašvaldību savienība. Latvijas Universitātes Akadēmiskais apgāds. 384 lpp.

Zaķis, G. (2003) Ūdenssaimniecības pārvaldes optimizācija Latvijā reǵionālās reformas perspektīvā [Optimization of Water Management in Latvia in the Perspective of the Regional Reform]. Magistra darbs. Rīga: Vides Zinātnes un pārvaldības institūts, Latvijas Universitāte. 114 lpp.

Zakis, G. (2004) Piekrastes vietējo pašvaldību sadarbība kā resurss ūdenssaimniecības pārvaldībai ilgtspējīgai attīstībai [Cooperation of Local Coastal Municipalities as a Resource in Water Management for Sustainable Development] Grām. Piekrastes ilgtspējīgas attīstības prakses Latvijā (23.-35. lpp.). Rīga: UNESCO Latvijas Nacionālā komisija.

Zakis, G. (2004) Specific Issues of Water Management in Coastal Municipalities for Sustainable Development. In Wise Coastal Practices for Sustainable Human Development. Proceedings of the Research Conference and Network Meeting Latvia, Roja, December 11-13, 2003 (pp. 72-81.). UNESCO/UNITWIN (WiCop). Rīga.

Zakis, G. (2007). Ūdenssaimniecības pārvalde Latvijā: Integratīvā pieeja [Water Management in Latvia: Integrative Approach]. Latvijas Universitātes Raksti, Sēr. Vadības zinātne, Nr. 717, 14.

Zaķis, G. (2007). Water Management in Coastal Local Governments: Specific Issues and Solutions. In Coastal Management and Communication: Case Studies Development. Proceedings of Integrated Coastal Management Research School, Latvia, 15-16 November 2006 (pp. 84-95). Riga. http://coastsust.net

Received 14 May 2008

\section{OPTIMĀLAS ŪDENSSAIMNIECĪBAS PĀRVALDES PREMISA LATVIJĀ}

Problēmas aktualitāti nosaka objektīva nepieciešamība mainīt ūdenssaimniecības pārvaldības sistēmu Latvijā pēc pievienošanās Eiropas Savienībai, atbilstoši pastāvošajām likumdošanas prasībām pašreiz notiekošās administratīvi teritoriālās reformas kontekstā. Pirminformācijas ievākšanai izmantotas empīiriskās zinātniski pētnieciskās metodes un konkrēto vietu, situāciju pētījumi vairāk nekā 50 vietējās pašvaldībās un ūdenssaimniecības uzṇēmumos visos valsts reǵionos. Izmantojot sistēmisku pieeju, izvērtētas ǵeogrāfiskā stāvokḷa, vēsturiskās attīstības, finanšu un cilvēkresursu kapacitātes radītās ietekmes uz pašvaldību iespējām organizēt ūdensapgādes un notekūdenu attīrīšanas pakalpojumus un uz uzṇēmumu iespējām tos sniegt. Pētīta ūdenssaimniecības attīstība pēdējos 20 gados, identificējot galvenās ūdenssaimniecības problēmas, izstrādājot un izvērtējot alternatīvos ūdenssaimniecības pārvaldes modeḷus un analizējot ūdenssaimniecības optimizāciju iespaidojošos faktorus. Rezultātā tika izstrādāts optimālas ūdenssaimniecības pārvaldības hierarhiskās pārvaldes, integrācijas un sadarbības modelis, kurā ietverti visi trīs pārvaldības līmeņi - nacionālais, reǵionālais un vietējais, jo sevišḳi akcentējot vertikālās un horizontālās sadarbības saites. Optimālu Latvijas ūdenssaimniecību raksturo decentralizētas pārvaldes modelis, kurā nacionālajā pārvaldes līmenī valsts organizē pārraudzību, koordināciju un kontroli, reğionālajā līmenī upju baseinu apsaimniekošanā iesaistās arī pašvaldības, veicot pārrobežu sadarbību monitoringa un vides aizsardzības pasākumu veikšanā, bet vietējā līmenī pašvaldības ar savu, vai piesaistīto resursu palīdzību realizē tiešu pakalpojumu sniegšanas organizēšanu iedzīvotājiem. Pētījuma galvenie secinājumi: optimālu ūdenssaimniecības pārvaldi nodrošina priekšnosacījumu komplekts - komplementāra pakete, kuras sastāvdaḷas veido pieejas, principi, struktūrkomponentes, instrumenti un integrācija, bet institucionālās, tehniskās, ekonomiskās un sociālās pieejas izteiktas praktisko rekomendāciju formā. 